\title{
Cannabinoid derivatives and the pharmacological management of pain
}

\author{
Derivados canabinóides e o tratamento farmacológico da dor
}

\author{
Marcos Adriano Lessa ${ }^{1}$, Ismar Lima Cavalcanti ${ }^{2}$, Nubia Verçosa Figueiredo ${ }^{3}$
}

DOI 10.5935/1806-0013.20160012

\section{ABSTRACT}

BACKGROUND AND OBJECTIVES: Medical properties of Cannabis sativa have been reported for centuries for the treatment of different disorders and, more recently, to manage pain. This study aimed at reviewing major pharmacological advances of the endocannabinoid system and the potential therapeutic use of some cannabinoid compounds to manage different types of pain. CONTENTS: A search was carried out in Pubmed, Scielo and Lilacs databases to identify studies and literature reviews on the pharmacology and therapeutic use of cannabinoids for pain. The following keywords were used: Cannabis sativa, tetra-hydrocannabinol, cannabidiol, sativex', cannador', cannabinoids, endocannabinoid, pain and neuropathic pain. Synthetic cannabinoids and Cannabis sativa extracts have shown analgesic effects in several clinical trials, suggesting their potential role for pain management, especially neuropathic pain. Synthetic cannabinoids and CS extracts have also induced anxiolytic effects when used as adjuvants to treat cancer pain, rheumatoid arthritis and multiple sclerosis. However, significant adverse effects, such as euphoria, depression and sedation limit the clinical use of such cannabinoids.

CONCLUSION: Further understanding of endocannabinoid system pharmacology, together with study results involving pain management with cannabinoid substances may be very useful for the development of drugs allowing a significant advance in the treatment of patients with painful syndromes, especially difficult to control. However, further studies are needed to confirm such findings and to determine the safety of such compounds.

Keywords: Cannabis, Endocannabinoids, Management, Pain, Pharmacology,

\footnotetext{
1. Fundação Oswaldo Cruz, Instituto Oswaldo Cruz, Laboratório de Investigação Cardiovascular, Rio de Janeiro, RJ, Brasil.

2. Universidade Federal Fluminense, Faculdade de Medicina, Departamento de Cirurgia Geral e Especializada, Niterói, RJ, Brasil.

3. Faculdade de Medicina da Universidade Federal do Rio de Janeiro, Departamento de Cirurgia, Curso de Especialização em Dor e Cuidados Paliativos Oncológicos. Rio de Janeiro, RJ, Brasil.
}

Submitted in September 01, 2015.

Accepted for publication in January 22, 2016.

Conflict of interests: none - Sponsoring sources: none.

Correspondence to:

Hospital Universitário Clementino Fraga Filho - Departamento de Cirurgia

Rua Professor Rodolpho Paulo Rocco, 255, 11ㅇ A. Setor F salas 11 e 12

21941-913 Rio de Janeiro, RJ, Brasil.

E-mail: malessa@ioc.fiocruz.br

(C) Sociedade Brasileira para o Estudo da Dor

\section{RESUMO}

JUSTIFICATIVA E OBJETIVOS: As propriedades medicinais da Cannabis sativa têm sido relatadas por muitos séculos para o tratamento de diversos distúrbios e, mais recentemente, para o tratamento da dor. O objetivo deste estudo foi revisar os principais avanços na farmacologia do sistema endocanabinóide e no potencial uso terapêutico de alguns compostos canabinóides no tratamento de diversas formas de dor.

CONTEÚDO: Foi realizada uma busca nos bancos de dados Pubmed, Scielo e Lilacs, identificando-se estudos e revisóes da literatura sobre a farmacologia e o uso terapêutico de substâncias canabinóides em dor. Nessa busca foram utilizadas as seguintes palavras-chaves: Cannabis sativa, tetra-hidrocanabinol, canabidiol, sativex", cannador", canabinóides, endocanabinóide, dor e dor neuropática. Os canabinóides sintéticos e os extratos de Cannabis sativa apresentaram efeito analgésico em diversos ensaios clínicos, sugerindo um potencial papel no tratamento da dor, em particular naquela de origem neuropática. Os canabinóides sintéticos e os extratos de Cannabis sativa também apresentaram efeitos ansiolíticos quando usados como adjuvantes no tratamento da dor no câncer, na artrite reumatoide e na esclerose múltipla. Porém, efeitos adversos significativos, como euforia, depressão e sedação limitam o uso clínico desses agentes canabinóides.

CONCLUSÁO: Um melhor conhecimento sobre a farmacologia do sistema endocanabinóide, juntamente com os resultados dos estudos envolvendo o tratamento da dor com substâncias de natureza canabinóide, podem ser de grande valor para o desenvolvimento de fármacos que permitam um avanço significativo na terapêutica de pacientes portadores de síndromes dolorosas, em particular nos casos de difícil controle. Porém, mais estudos são necessários para confirmar esses achados e determinar a segurança desses compostos.

Descritores: Cannabis, Dor, Endocanabinóides, Farmacologia, Tratamento.

\section{INTRODUCTION}

Among plant species domesticated by men, may be none is as versatile as Cannabis sativa (CS). Popularly known in Brazil by its African name (maconha), marijuana is part of humankind history for hundreds of years. From Gutenberg's Bible and paper money, to the original text of the American constitution, CS-derived fiber has been broadly used to manufacture paper. In addition to its psychoactive effect, CS has nutritional, medicinal and industrial importance as food, drug, fiber and fuel oil, in addition to its use in religious cere- 
monies in different parts of the world. Recently, in Brazil, the controversial discussion about CS for medical use has been intensified due to the need for legal authorization to import cannabidiol for the treatment of children with seizures refractory to conventional therapies.

Medical use of CS has been recommended for different clinical conditions for many centuries ${ }^{1}$. In this sense, it is worth stressing that the two most widely used classes of drugs to manage pain (opioids and anti-inflammatory drugs), have vegetal origin. Popular consumption of willow bark to control pain and subsequent results of this plant have led to the development of aspirin and then to the discovery of the role of prostaglandins on inflammation and pain. Opium, obtained from poppy sap, has given origin to morphine, which is the prototype of opioid analgesics and which has allowed the characterization of several peptides, receptors, enzymes and signaling pathways which form the endogenous opioid system.

As from these breakthroughs there has been major scientifictechnological development related to the manufacturing and use of these products and their derivatives. Similarly, studies related to CS pharmacological properties and its potential therapeutic use have gained major impulse in recent decades, especially as from the isolation in 1964 of its major psychoactive component, $\Delta^{9}$-tetra-hydrocannabinol (THC). This advance has allowed for the discovery of the endogenous "cannabinergic" system, subsequently called endocannabinoid system (ECS) or endogenous cannabinoid. Several clinical and experimental evidences are suggesting the ECS participation in pain modulation ${ }^{1}$, opening space for pharmaceutical developments in this area.

This study aimed at reviewing major pharmacological advances of endocannabinoid system pharmacology and the therapeutic use of some cannabinoid compounds to manage different types of pain.

\section{CONTENTS}

Selected articles for this review were identified by means of electronic query in Pubmed, Scielo and Lilacs databases. The following keywords were used: Cannabis sativa, tetra-hydrocannabinol, cannabidiol, sativex', cannador, cannabinoids, endocannabinoid, pain and neuropathic pain. Selection was made up of studies and literature reviews on pharmacology and therapeutic use of cannabinoid derivatives for pain. Studies using drugs produced as from raw plant extract were also included.

Then, a review of references of articles was carried out and clinical and experimental studies were included. Considering the broad individual variation of different studied samples, dose or composition of different cannabinoids were not arbitrated. Studies using smoked CS were not included in this review due characteristics related to its use, such as previous experience of users, which impair the performance of a blind study, use of devices for plant combustion, etc.

\section{PHARMACOLOGY OF THE ENDOCANNABINOID SYSTEM}

In 1988, the first cannabinoid receptor was identified ${ }^{2}$ and was susequently called endocannabinoid receptor 1 (CB $)$. In 1993, a second receptor was discovered and called endocannabinoid receptor $2\left(\mathrm{CB}_{2}\right)^{3}$. Both receptors belong to the family of cell membrane proteins coupled to proteins Gi/o. Tissue distribution of $\mathrm{CB}_{1}$, especially in basal ganglia, cerebellum, hippocampus, cortex, spinal cord and peripheral nerves, explains most part of psychotropic effects of endocannabinoid substances ${ }^{4}$. $\mathrm{CB}_{2}$ receptors are found in immune system cells ${ }^{5}$, which partially may explain the effects of these substances on pain and inflammation.

Cannabinoids are divided in three types: phytocannabinoids, synthetic cannabinoids and endogenous cannabinnoids or endocannabinoids, which are natural chemical substances especially represented by anandamide ( $\mathrm{N}$-arachidonoil ethanolamine) and by 2-arachidonoil glycerol. Anandamide and 2-arachidonoil glycerol are compounds found in several animals, especially those hibernating, and are physiologically related to functions such as "relax, eat, sleep, forget and protect"6.

ECS includes endocannabinoids, their synthesis and catabolism enzymes and their corresponding receptors ${ }^{7}$. The name anandamide derives from the Sanskrit term ananda, which means ecstasy, supreme happiness, joy or blessedness. Both anandamide and 2-arachidonoil glycerol are agonists of receptors $\mathrm{CB}_{1}$ and $\mathrm{CB}_{2}$. However, due to the involvement in a larger number of metabolic pathways, cell and tissue levels of 2-arachidonoil glycerol are higher as compared to anandamide. Clinical and experimental evidences suggest that ECS, which is made up of endocannabinoid receptors, its endogenous ligands and synthesis and metabolic enzymes, may play important physiological role in regulating several signaling pathways, including those involved with pain pathophysiology.

Most endocannabinoids identified to date are derived from long chain poly-unsaturated fatty acids, specifically arachidonic acid. So, anandamide and 2-arachidonoil glycerol are formed by phospholipid-dependent pathways, the synthesizing enzymes of which are selective $\mathrm{N}$-acyl phosphate diethanolamine phospholipase D and selective sn-1-diaglycerol lipase, respectively ${ }^{8,9}$. After release, anandamide and 2-arachinodoil glycerol suffer neuronal reuptake process and then are rapidly metabolized in inactive compounds by FAAH (fatty acid amide hydrolase) and by MGL lipase (monoacyl glycerol), respectively ${ }^{10,11}$. Anandamide is hydrolized by FAAH in arachidonic acid breakdown products and ethanolamine ${ }^{12} .2$-arachidonoil glycerol is hydrolyzed by the MGL enzyme in arachidonic acid and glycerol $^{13}$. FAAH is a post-synaptic enzyme which controls anandamide levels close to synthesis sites, and MGL is a pre-synaptic enzyme ${ }^{14}$ controlling 2-arachidonoil glycerol levels after its action on $\mathrm{CB}_{1}$ receptors. It is intriguing to notice that both endocannabinoids are degraded both in pre-synaptic (2-arachidonoil glycerol) and post-synaptic (anandamide) ways, thus making modulation of FAAH and MGL activity an important pharmacological target with potential therapeutic use. 
ECS us active both in central (CNS) and peripheral nervous systems acting on spinal, supraspinal and peripheral pain modulation ${ }^{15,16}$. Endocannabinoid substances are produced in CNS by demand aiming at decreasing sensitivity to pain ${ }^{17}$. Several studies have already documented high ECS activity in pain integration key-centers ${ }^{18-22}$. Endocannabinoids seem to be mediators involved in the modulation of painful phenomena, such as wind up $^{23}$ and allodynia ${ }^{24}$. Peripherally, activation of $\mathrm{CB}_{1}$ receptors seems to have important role in decreasing both hyperalgesia and allodynia ${ }^{25,26}$.

By means of $\mathrm{CB}_{1}$ and $\mathrm{CB}_{2}$-mediated mechanisms, ECS seems to play important role also in peripheral pain, particularly in inflammatory processes and hyperalgesia ${ }^{26}$. Astrocytes and microglia-mediated inflammatory response depends on mechanisms involving activation of spinal $\mathrm{CB}_{2}$ receptors ${ }^{27}$. THC inhibits prostaglandin E-2 synthesis ${ }^{28}$ and stimulates lipoxygenase ${ }^{29}$, however it does not affect cycloxigenase- 1 and cycloxigenase- 2 synthesis ${ }^{30}$. In addition to anti-inflammatory action, cannabinoids also have antioxidant activity via noncannabinoid mechanisms ${ }^{31}$.

Cannabidiol, which is a phytocannabinoid present in high concentrations in raw CS extract, inhibits both FAAH and anandamide reuptake ${ }^{32}$, in addition to decreasing THC liver metabolism, thus decreasing psychotic changes and signs and symptoms of anxiety ${ }^{33}$. So, cannabidiol seems to act as ECS mediator, attenuating THC effects on behavior ${ }^{34}$, appetite ${ }^{35}$ and short term memory ${ }^{36}$. Cannabidiol seems to be effective to control endometriosis pain, among other conditions, especially those which may be considered ECS-mediated pain ${ }^{37}$. High cannabinoid activity has been already documented in different mediator areas of painful response in the gastrointestinal $\operatorname{tract}^{38,39}$.

Cannabinoid substances specifically inhibit glutamate release in the hippocampus ${ }^{40}$ decreasing NMDA-mediated painful response $^{28}$ so, they could be useful for the management of NMDA-mediated painful disorders ${ }^{41}$, such as migraine, fibromyalgia and other diseases where glutamatergic mechanisms seem to be involved ${ }^{42}$.

A promising pharmacological approach of particular interest for pain therapy is the combination of cannabinoids and opioids. Cannabinoid substances and ECS have different interaction levels with the endogenous opioid system. Known cannabinoid system interaction mechanism with the opioid system are: endorphin release ${ }^{43}$; opioid sparing effect ${ }^{44}$; decreased phenomena of opioids tolerance and withdrawal ${ }^{45}$; and analgesic rescue by opioids after the tolerance phenomenon ${ }^{46}$. It is interesting to notice that it seems to be pharmacological synergy between cannabinoid and opioid substances and that this phenomenon could potentiate analgesic effects of both drugs, thus decreasing doses without impairing therapeutic effects, in addition to significantly decreasing adverse effects of both drugs.

Based on above-mentioned action mechanisms, as well as on described pharmacological interactions for cannabinoid substances and ECS, it is possible to suggest that a functional ECS change may significantly contribute for the onset or worsening of pathological pain.

\section{CLINICAL TRIALS ON THE USE OF SYNTHETIC CANNABINOIDS AND PAIN}

Classically indicated for treating loss of appetite in human immunodeficiency virus (HIV) patients and to treat nausea and vomiting of patients under chemotherapy, dronabinol is available in the American market with the commercial name of marinol in gelatin capsules of $2.5,5$ and $10 \mathrm{mg}$. Dronabinol has been used in studies with neuropathic pain patients $^{47,48}$, but without significant benefit in pain control, in addition to presenting major adverse effects which have limited its use. For multiple sclerosis pain, dronabinol has produced significant relief $f^{49}$, however there has been no evident effect on postoperative pain ${ }^{50}$. Dronabinol has been used to relieve itching in jaundice patients, however there are no controlled studies in this area, being this effect described only as case reports ${ }^{51}$. In a crossover study, dronabinol was evaluated in patients with chronic non-cancer pain under opioids and results were significant with regard to pain relief ${ }^{52}$. In a study with patients with spinal cord injury and neuropathic pain, dronabinol was not better than diphenhydramine ${ }^{53}$.

Nabilone, with commercial name of Cesamet is another THC semi-synthetic analog, available in oral capsules of 1 and $2 \mathrm{mg}$ in the United States and in Europe. It has more prolonged therapeutic effect as compared to THC for having pharmacological potency approximately 10 times higher, as well as for presenting longer half-life ${ }^{54}$. Notwithstanding reports of the use of nabilone to treat neuropathic pain ${ }^{55}$ and other painful syndromes ${ }^{56}$, its classic indication is as antiemetic agent for patients under chemotherapy. In polyneuropathy patients, nabilone has resulted in significant pain improvement after three months of use ${ }^{57}$.

A controlled study with nabilone three times a day in patients with postoperative pain has shown increased visual analog scale (VAS) scores $^{58}$. In a double-blind study with mixed spastic syndrome patients, nabilone has improved pain scores as compared to placebo ${ }^{59}$, however there has been no improvement in other parameters such as spasticity, motor function or daily activities. In a double-blind crossover study comparing nabilone and dihydrocodeine for neuropathic pain ${ }^{60}$, both drugs had no satisfactory results. In a different controlled study with fibromyalgia patients, nabilone versus placebo has shown significant improvement in VAS and anxiolytic effects ${ }^{61}$.

A more recent study with nabilone versus amitriptyline with fibromyalgia patients has shown beneficial effects only for sleep-related parameters, without significant results for pain, mood or even quality of life ${ }^{62}$. Bestard \& Toth, evaluating nabilone versus gabapentin, have found comparable effects in peripheral neuropathic pain improvement and in other symptoms ${ }^{63}$. However, in general, significant adverse effects, especially sedation and euphoria, have also limited its use in most studies.

Ajulemic acid, another synthetic THC analog ${ }^{64}$, was used by Karst et al. in a controlled clinical trial with patients with peripheral neuropathic pain, showing possible improvement of pain-related symptoms ${ }^{65}$. 


\section{CLINICAL TRIALS ON THE USE OF CANNABIS EX- TRACTS AND PAIN}

Cannador is administered in oral capsules and is manufactured as from raw CS extract with different THC/cannabidiol percentages ${ }^{33}$, but which in general is approximately 2:1. Cannador was used in patients with spasticity changes in multiple sclerosis ${ }^{66,67}$ and has shown slight postoperative pain relief ${ }^{68}$. However, side effects, such as sedation and psychoactive changes, were evident ${ }^{68}$.

Sativex is produced as from raw plant extract and is administered as oral spray which combines a partial agonist effect on $\mathrm{CB}_{1}$ and $\mathrm{CB}_{2}$. In addition to THC and cannabidiol, Sativex has in its composition other minor cannabinoids, propylene glycol, terpenoids, ethanol and flavoring mint excipient ${ }^{33,69}$. Sativex has been used to treat cancer pain refractory to opioids and to relieve symptoms related to multiple sclerosis, such as central neuropathic pain and spasticity. Sativex is formulated as from two CS strains where THC and cannabidiol predominate ${ }^{70}$. Sativex" has shown satisfactory results in patients with pain refractory to conventional treatment and/or with neurogenic symptoms ${ }^{71}$ and in patients with untreatable chronic pain ${ }^{72}$. In patients with chronic pain by brachial plexus avulsion, Sativex has also significantly decreased pain ${ }^{73}$. Sativex for rheumatoid arthritis patients has significantly improved pain both at rest and at movement ${ }^{74}$. Sativex was also used in patients with peripheral neuropathic pain associated to allodynia and again has decreased pain and allodynia levels ${ }^{75}$. In virtually all chronic pain clinical trials, Sativex has significantly improved quality of sleep, not due to drug sedative effect, but rather by significantly decreasing symptoms ${ }^{76}$. Sativex adverse effects may be considered mild, being most common: bitter taste, oral burning, dry mouth, dizziness, nausea and fatigue. Psychoactive sequelae are early and transient and have been significantly decreased by a slower and less aggressive titration scheme.

\section{CONCLUSION}

Pharmacological studies and clinical trials partially support the use of cannabinoid agents as analgesics for chronic pain, creating the perspective that drugs based on phytocannabinoids and synthetic cannabinoids may be used as adjuvant for pain control, especially for that of neuropathic origin. Due to their unique pharmacological profile, with multimodal effect and low risk of adverse effects, cannabinoid agents have potential to offer health professionals a useful option to treat neuropathic pain. However, further studies are needed to confirm the efficacy and safety of these compounds for patients, especially with regard to the incidence and intensity of adverse effects during long term treatment.

\section{REFERENCES}

1. Bonfa L, Vinagre RC, de Figueiredo NV. [Cannabinoids in chronic pain and palliative care]. Rev Bras Anestesiol, 2008;58(3):267-79. English, Portuguese.

2. Devane WA, Dysarz FA 3rd, Johnson MR, Melvin LS, Howlett AC. Determination and characterization of a cannabinoid receptor in rat brain. Mol Pharmacol. 1988;34(5):605-13.

3. Munro S, Thomas KL, Abu-Shaar M. Molecular characterization of a peripheral receptor for cannabinoids. Nature. 1993;365(6441):61-5.

4. Ameri A. The effects of cannabinoids on the brain. Prog Neurobiol. 1999;58(4):315-48

5. Porter AC, Felder CC. The endocannabinoid nervous system: unique opportunities for therapeutic intervention. Pharmacol Ther. 2001;90(1):45-60.

6. Di Marzo V, Bisogno T, De Petrocellis L. Endocannabinoids: new targets for drug development. Curr Pharm Des. 2000;6(13):1361-80.

7. Pacher P, Bátkai S, Kunos G. The endocannabinoid system as an emerging target of pharmacotherapy. Pharmacol Rev. 2006;58(3):389-462.

8. Okamoto Y, Morishita J, Tsuboi K, Tonai T, Ueda N. Molecular characterization of a phospholipase D generating anandamide and its congeners. J Biol Chem. 2004;279(7):5298-305.

9. Bisogno T, Howell F, Williams G, Minassi A, Cascio MG, Ligresti A, et al. Cloning of the first sn1-DAG lipases points to the spatial and temporal regulation of endocannabinoid signaling in the brain. J Cell Biol. 2003;163(3):463-8.

10. De Petrocellis L, Cascio MG, Di Marzo V. The endocannabinoid system: a general view and latest additions. Br J Pharmacol. 2004;141(5):765-74.

11. Bisogno T, De Petrocellis L, Di Marzo V. Fatty acid amide hydrolase, an enzyme with many bioactive substrates. Possible therapeutic implications. Curr Pharm Des. 2002;8(7):533-47

12. Cravatt BF, Giang DK, Mayfield SP, Boger DL, Lerner RA, Gilula NB. Molecular characterization of an enzyme that degrades neuromodulatory fatty-acid amides. Nature. 1996;384(6604):83-7.

13. Dinh TP, Freund TF, Piomelli D. A role for monoglyceride lipase in 2-arachidonoylglycerol inactivation. Chem Phys Lipids. 2002;121(1-2):149-58.

14. Gulyas AI, Cravatt BF, Bracey MH, Dinh TP, Piomelli D, Boscia F, et al. Segregation of two endocannabinoid-hydrolyzing enzymes into pre- and postsynaptic compartments in the rat hippocampus, cerebellum and amygdala. Eur J Neurosci. 2004;20(2):441-58.

15. Walker JM, Hohmann AG. Cannabinoid mechanisms of pain suppression. Handb Exp Pharmacol. 2005;(168):509-54.

16. Rahn EJ, Hohmann AG. Cannabinoids as pharmacotherapies for neuropathic pain from the bench to the bedside. Neurotherapeutics. 2009;6(4):713-37.

17. Richardson JD, Aanonsen L, Hargreaves KM. SR 141716A, a cannabinoid receptor antagonist, produces hyperalgesia in untreated mice. Eur J Pharmacol. 1997;319(23):R3-4.

18. Walker JM, Huang SM, Strangman NM, Tsou K, Sañudo-Peña MC. Pain modulation by release of the endogenous cannabinoid anandamide. Proc Natl Acad Sci U S A. 1999;96(21):12198-203.

19. Walker JM, Hohmann AG, Martin WJ, Strangman NM, Huang SM, Tsou K. The neurobiology of cannabinoid analgesia. Life Sci. 1999;65(6-7):665-73.

20. Martin WJ, Hohmann AG, Walker JM. Suppression of noxious stimulus-evoked activity in the ventral posterolateral nucleus of the thalamus by a cannabinoid agonist: correlation between electrophysiological and antinociceptive effects. J Neurosci. 1996;16(20):6601-11.

21. Hohmann AG, Martin WJ, Tsou K, Walker JM. Inhibition of noxious stimulus -evoked activity of spinal cord dorsal horn neurons by the cannabinoid WIN 55,2122. Life Sci. 1995;56(23-24):2111-8.

22. Richardson JD, Aanonsen L, Hargreaves KM. Antihyperalgesic effects of spinal cannabinoids. Eur J Pharmacol. 1998;345(2):145-53.

23. Strangman NM, Walker JM. Cannabinoid WIN 55,212-2 inhibits the activity-dependent facilitation of spinal nociceptive responses. J Neurophysiol. 1999;82(1):472-7.

24. Rahn EJ, Makriyannis A, Hohmann AG. Activation of cannabinoid CB1 and CB2 receptors suppresses neuropathic nociception evoked by the chemotherapeutic agent vincristine in rats. Br J Pharmacol. 2007;152(5):765-77.

25. Ibrahim MM, Porreca F, Lai J, Albrecht PJ, Rice FL, Khodorova A, et al. CB2 cannabinoid receptor activation produces antinociception by stimulating peripheral release of endogenous opioids. Proc Natl Acad Sci U S A. 2005;102(8):3093-8.

26. Richardson JD, Kilo S, Hargreaves KM. Cannabinoids reduce hyperalgesia and in flammation via interaction with peripheral CB1 receptors. Pain. 1998;75(1):111-9.

27. Luongo L, Palazzo E, Tambaro S, Giordano C, Gatta L, Scafuro MA, et al 1-(2',4'-dichlorophenyl)-6-methyl-N-cyclohexylamine-1,4-dihydroindeno[1,2-c] pyraz ole-3-carboxamide, a novel CB2 agonist, alleviates neuropathic pain through functional microglial changes in mice. Neurobiol Dis. 2010;37(1):177-85.

28. Burstein S, Levin E, Varanelli C. Prostaglandins and cannabis. II. Inhibition of biosynthesis by the naturally occurring cannabinoids. Biochem Pharmacol. 1973;22(22):2905-10.

29. Fimiani C, Liberty T, Aquirre AJ, Amin I, Ali N, Stefano GB. Opiate, cannabinoid, and eicosanoid signaling converges on common intracellular pathways nitric oxide coupling. Prostaglandins Other Lipid Mediat. 1999;57(1):23-34.

30. Russo EB, Hohmann AG. Role of Cannabinoids in Pain Management. In: Deer TR, Leong MS, Buvanendran A, Gordin V, Kim PS, Panchal SJ, Ray AL, editors. Com- 
prehensive Treatment of Chronic Pain by Medical, Interventional, and Integrative Approaches - The American Academy of Pain Medicine Textbook on Patient Management. New York: Springer; 2013. 1120-64p.

31. Hampson AJ, Grimaldi M, Axelrod J, Wink D. Cannabidiol and (-)Delta9-tetrahydrocannabinol are neuroprotective antioxidants. Proc Natl Acad Sci U S A. 1998;95(14):8268-73.

32. Bisogno T, Hanus L, De Petrocellis L, Tchilibon S, Ponde DE, Brandi I, et al. Molecular targets for cannabidiol and its synthetic analogues: effect on vanilloid VR1 receptors and on the cellular uptake and enzymatic hydrolysis of anandamide. $\mathrm{Br} \mathrm{J}$ Pharmacol. 2001;134(4):845-52.

33. Russo E, Guy GW. A tale of two cannabinoids: the therapeutic rationale for combining tetrahydrocannabinol and cannabidiol. Med Hypotheses. 2006;66(2):234-46.

34. Morgan CJ, Curran HV. Effects of cannabidiol on schizophrenia-like symptoms in people who use cannabis. Br J Psychiatry. 2008;192(4):306-7.

35. Morgan CJ, Freeman TP, Schafer GL, Curran HV. Cannabidiol attenuates the appetitive effects of Delta 9-tetrahydrocannabinol in humans smoking their chosen cannabis. Neuropsychopharmacology. 2010;35(9):1879-85.

36. Morgan CJ, Schafer G, Freeman TP, Curran HV. Impact of cannabidiol on the acute memory and psychotomimetic effects of smoked cannabis: naturalistic study: naturalistic study [corrected]. Br J Psychiatry. 2010;197(4):285-90.

37. Dmitrieva N, Nagabukuro H, Resuehr D, Zhang G, McAllister SL, McGinty KA, et al. Endocannabinoid involvement in endometriosis. Pain. 2010;151(3):703-10.

38. Izzo AA, Camilleri M. Emerging role of cannabinoids in gastrointestinal and liver diseases: basic and clinical aspects. Gut. 2008;57(8):1140-55.

39. Izzo AA, Sharkey KA. Cannabinoids and the gut: new developments and emerging concepts. Pharmacol Ther. 2010;126(1):21-38.

40. Shen M, Piser TM, Seybold VS, Thayer SA. Cannabinoid receptor agonists inhibit glutamatergic synaptic transmission in rat hippocampal cultures. J Neurosci. 1996;16(14):4322-34.

41. Nicolodi M, Volpe AR, Sicuteri F. Fibromyalgia and headache. Failure of serotonergic analgesia and N-methyl-D-aspartate-mediated neuronal plasticity: their common clues. Cephalalgia. 1998;18(Suppl 21):41-4.

42. Russo EB. Clinical endocannabinoid deficiency (CECD): can this concept explain therapeutic benefits of cannabis in migraine, fibromyalgia, irritable bowel syndrome and other treatment-resistant conditions? Neuro Endocrinol Lett. 2004;25(1-2):31-9.

43. Manzanares J, Corchero J, Romero J, Fernandez-Ruiz JJ, Ramos JA, Fuentes JA. Chronic administration of cannabinoids regulates proenkephalin mRNA levels in selected regions of the rat brain. Brain Res Mol Brain Res. 1998;55(1):126-32.

44. Cichewicz DL, Martin ZL, Smith FL, Welch SP. Enhancement mu opioid antinociception by oral delta9-tetrahydrocannabinol: dose-response analysis and receptor identification. J Pharmacol Exp Ther. 1999;289(2):859-67.

45. Cichewicz DL, Welch SP. Modulation of oral morphine antinociceptive tolerance and naloxone-precipitated withdrawal signs by oral Delta 9-tetrahydrocannabinol. J Pharmacol Exp Ther. 2003;305(3):812-7.

46. Cichewicz DL, McCarthy EA. Antinociceptive synergy between delta(9)-tetrahydrocannabinol and opioids after oral administration. J Pharmacol Exp Ther. 2003;304(3):1010-5.

47. Clermont-Gnamien S, Atlani S, Attal N, Le Mercier F, Guirimand F, Brasseur L. [The therapeutic use of D9-tetrahydrocannabinol (dronabinol) in refractory neuropathic pain]. Presse Med. 2002;31(39 Pt 1):1840-5.

48. Attal N, Brasseur L, Guirimand D, Clermond-Gnamien S, Atlami S, Bouhassira D. Are oral cannabinoids safe and effective in refractory neuropathic pain? Eur J Pain. 2004;8(2):173-7.

49. Svendsen KB, Jensen TS, Bach FW. Does the cannabinoid dronabinol reduce central pain in multiple sclerosis? Randomised double blind placebo controlled crossover trial. BMJ. 2004;329(7460):253.

50. Buggy DJ, Toogood L, Maric S, Sharpe P, Lambert DG, Rowbotham DJ. Lack of analgesic efficacy of oral delta-9-tetrahydrocannabinol in postoperative pain. Pain. 2003;106(1-2):169-72.

51. Neff GW, O’Brien CB, Reddy KR, Bergasa NV, Regev A, Molina E, et al. Preliminary observation with dronabinol in patients with intractable pruritus secondary to cholestatic liver disease. Am J Gastroenterol. 2002;97(8):2117-9.

52. Narang S, Gibson D, Wasan AD, Ross EL, Michna E, Nedeljkovic SS, et al. Efficacy of dronabinol as an adjuvant treatment for chronic pain patients on opioid therapy. J Pain. 2008;9(3):254-64.
53. Rintala DH, Fiess RN, Tan G, Holmes SA, Bruel BM. Effect of dronabinol on central neuropathic pain after spinal cord injury: a pilot study. Am J Phys Med Rehabil. 2010;89(10):840-8

54. Lemberger L, Rubin A, Wolen R, DeSante K, Rowe H, Forney R, et al. Pharmacokinetics, metabolism and drug-abuse potential of nabilone. Cancer Treat Rev. 1982;9(Suppl B):17-23.

55. Notcutt W, Price M, Chapman G. Clinical experience with nabilone for chronic pain Pharm Sci. 1997:3:551-5.

56. Berlach DM, Shir Y, Ware MA. Experience with the synthetic cannabinoid nabilone in chronic noncancer pain. Pain Med. 2006;7(1):25-9.

57. Toth $\mathrm{C}, \mathrm{Au} \mathrm{S}$. A prospective identification of neuropathic pain in specific chronic polyneuropathy syndromes and response to pharmacological therapy. Pain. 2008;138(3):657-66.

58. Beaulieu P. Effects of nabilone, a synthetic cannabinoid, on postoperative pain. Can J Anaesth. 2006;53(8):769-75.

59. Wissel J, Haydn T, Muller J, Brenneis C, Berger T, Poewe W, et al. Low dose treatment with the synthetic cannabinoid Nabilone significantly reduces spasticity-related pain: a double-blind placebo-controlled crossover trial. J Neurol. 2006;253(10):1337-41.

60. Frank B, Serpell MG, Hughes J, Matthews JN, Kapur D. Comparison of analgesic effects and patient tolerability of nabilone and dihydrocodeine for chronic neuropathic pain: randomised, crossover, double blind study. BMJ. 2008;336(7637):199-201.

61. Skrabek RQ, Galimova L, Ethans K, Perry D. Nabilone for the treatment of pain in fibromyalgia. J Pain. 2008;9(2):164-73.

62. Ware MA, Fitzcharles MA, Joseph L, Shir Y. The effects of nabilone on sleep in fibromyalgia: results of a randomized controlled trial. Anesth Analg. 2010;110(2):604-10.

63. Bestard JA, Toth CC. An open-label comparison of nabilone and gabapentin as adjuvant therapy or monotherapy in the management of neuropathic pain in patients with peripheral neuropathy. Pain Pract. 2011;11(4):353-68.

64. Dyson A, Peacock M, Chen A, Courade JP, Yaqoob M, Groarke A, et al. Antihyperalgesic properties of the cannabinoid CT-3 in chronic neuropathic and inflammatory pain states in the rat. Pain. 2005;116(1-2):129-37.

65. Karst M, Salim K, Burstein S, Conrad I, Hoy L, Schneider U. Analgesic effect of the synthetic cannabinoid CT-3 on chronic neuropathic pain: a randomized controlled trial. JAMA. 2003;290(13):1757-62.

66. Zajicek J, Fox P, Sanders H, Wright D, Vickery J, Nunn A, et al. Cannabinoids for treatment of spasticity and other symptoms related to multiple sclerosis (CAMS study): multicentre randomised placebo-controlled trial. Lancet. 2003;362(9395):1517-26.

67. Zajicek JP, Sanders HP, Wright DE, Vickery PJ, Ingram WM, Reilly SM, et al. Cannabinoids in multiple sclerosis (CAMS) study: safety and efficacy data for 12 months follow up. J Neurol Neurosurg Psychiatry. 2005;76(12):1664-9.

68. Holdcroft A, Maze M, Dore C, Tebbs S, Thompson S. A multicenter dose-escalation study of the analgesic and adverse effects of an oral cannabis extract (Cannador) for postoperative pain management. Anesthesiology. 2006;104(5):1040-6.

69. McPartland JM, EB. R. Cannabis and cannabis extracts: greater than the sum of their parts? J Cannabis Ther. 2001;1(3-4):103-32.

70. E. dM. The breeding of cannabis cultivars for pharmaceutical end uses. In: Guy GW, Whittle BA. editors. Medicinal uses of cacannabis and cannabinoids. London: Pharmaceutical Press; 2004. 55-70p.

71. Wade DT, Robson P, House H, Makela P, Aram J. A preliminary controlled study to determine whether whole-plant cannabis extracts can improve intractable neurogenic symptoms. Clin Rehabil, 2003;17(1):21-9.

72. Notcutt W, Price M, Miller R, Newport S, Phillips C, Simmons S, et al. Initial experiences with medicinal extracts of cannabis for chronic pain: results from 34 ' $\mathrm{N}$ of 1 ' studies. Anaesthesia. 2004;59(5):440-52.

73. Berman JS, Symonds C, Birch R. Efficacy of two cannabis based medicinal extracts for relief of central neuropathic pain from brachial plexus avulsion: results of a randomised controlled trial. Pain. 2004;112(3):299-306.

74. Blake DR, Robson P, Ho M, Jubb RW, CS. M. Preliminary assessment of the efficacy, tolerability and safety of a cannabis-based medicine (Sativex) in the treatment of pain caused by rheumatoid arthritis. Rheumatology. 2006;45(1):50-2.

75. Nurmikko TJ, Serpell MG, Hoggart B, Toomey PJ, Morlion BJ, Haines D. Sativex successfully treats neuropathic pain characterised by allodynia: a randomised, double-blind, placebo-controlled clinical trial. Pain. 2007;133(1-3):210-20.

76. Russo EB, Guy GW, Robson PJ. Cannabis, pain, and sleep: lessons from therapeutic clinical trials of Sativex, a cannabis-based medicine. Chem Biodivers. 2007;4(8):1729-43. 